\title{
Analisis dampak belanja modal dan tingkat pengangguran terhadap tingkat kemiskinan di Kabupaten Tebo
}

\author{
Yoga Amanda*; Zamzami; Selamet Rahmadi \\ Prodi Ekonomi Pembangunan, Fakultas Ekonomi dan Bisnis, Universitas Jambi \\ *E-mail korespondensi: yogaamanda06709t@gmail.com
}

\begin{abstract}
This study aims to determine and analyze: 1). Changes that occur in capital expenditure, unemployment, and the number of poor people in Tebo Regency during 2004-2018, 2). Effect of capital expenditure and unemployment rates on poverty levels in Tebo Regency during 2004-2018. The data analysis method used in this study uses the formula of development and multiple linear regression. Based on the results of research during 20042018 in Tebo Regency, the average capital expenditure increases 20.99 percent every year, the number of unemployed people has increased 28.57 percent every year and the average number of poor people has decreased 0, 42 percent every year. Capital expenditure and unemployment rate influence reducing the level of poverty in Tebo Regency during 20042018 with a regression coefficient value of capital expenditure and the unemployment rate which has a negative regression coefficient.
\end{abstract}

\section{Keywords: Capital expenditure, Poverty rate, Unemployment rate}

\begin{abstract}
Abstrak
Penelitian ini bertujuan untuk mengetahui dan menganalisis : 1). Perubahan yang terjadipada belanja modal, jumlah pengangguran dan jumlah penduduk miskin di Kabupaten Tebo selama tahun 2004-2018, 2). Pengaruh belanja modal dan tingkat pengangguran terhadap tingkat kemiskinan di Kabupaten Tebo selama tahun 2004-2018. Metode analisis data yang digunakan dalam penelitian ini menggunakan rumus perkembangan dan regresi linier berganda.Berdasarkan hasil penelitian selama tahun 2004-2018 di Kabupaten Tebo, belanja modal rata-rata meningkat 20,99 persen setiap tahun, jumlah pengangguran rata-rata mengalami peningkatan 28,57 persen setiap tahun dan jumlah penduduk miskin rata-rata mengalami penurunan 0,42 persen setiap tahun. Belanja modal dan tingkat pengangguran miliki pengaruh dalam menurunkan tingkat kemiskinan di Kabupaten Tebo selama tahun 2004-2018 dengan nilai koefisien regresi dari belanja modal dan tingkat pengangguran yang memiliki nilai koefisien regresinegatif yaitu $-6,869632$ dan $-2,344968$.
\end{abstract}

Kata kunci : Belanja modal, Tingkat kemiskinan, Tingkat pengangguran

\section{PENDAHULUAN}

Pelaksanaan pembangunan yang dilaksanakan suatu negara atau daerah pada hakekatnya bertujuan untuk meningkatkan kesejahteraan masyarakat. Peningkatan kesejahteraan masyarakat suatu daerah ditandai dengan semakin meningkatnya pendapatan yang diperoleh masyarakat. Peningkatan pendapatan masyarakat suatu daerah diharapkan akan membuat masyarakat mampu memenuhi kebutuhan hidupnya sehari- hari, terutama kebutuhan dasar yaitu kebutuhan primer. Kemampuan masyarakat dalam memenuhi kebutuhan primer nantinya memberi pengaruh pada semakin berkurangnya jumlah masyarakat atau penduduk dalam keadaan miskin. 
Pentingnya suatu daerah dalam mengurangi jumlah penduduk miskin terus diupayakan dan dilaksanakan berkelanjutan setiap tahunnya. Kemiskinan merupakan suatu masalah yang sangat kompleks dan bersifat multidimensional dalam pembangunandaerah, untuk itu upaya pengentasan kemiskinan menurut Soegijoko (2011) harus dilakukan secara komprehensif. Tingginya tingkat kemiskinan suatu negara atau daerah bisa dijadikan sebagai indikator kurang berhasilnya pembangunan dan sekaligus menggambarkan tidak meratanya pembangunan yang dilaksanakan. (Todaro, 2010).

Upaya menanggulangi atau mengurangi tingkat kemiskinan dapat dilakukan, jika daerah melaksanakan pembangunan mampu menciptakan pertumbuhan ekonomi yang tinggi secara berkelanjutan dan diikuti dengan kemampuan menciptakan pemerataan di segala aspek. (Haughton dan Khandker, 2012). Kemampuan menciptakan pertumbuhan ekonomi tinggi dan disertai pemerataan disuatu negara atau daerah akan memberi dampaksangat luas dalam perekonomian. Pertumbuhan ekonomi tinggi dapat mendorong terciptanya barang dan jasa yang dihasilkan dalam jumlah yang besar yang pada akhirnya mendorong peningkatan produktivitas. Produktivitas yang meningkat sebagai akibat meningkatnya barang dan jasa yang dihasilkan akan mendorong meningkatnya kebutuhan akan tenaga kerja dan mampu menciptakan lapangan kerja yang besar. (Todaro dan Smith, 2011).

Terciptanya lapangan kerja serta kemampuan menyerap tenaga kerja dari meningkatnya pertumbuhan ekonomi melalui meningkatnya aktivitas ekonomi akan memberi dampak pada peningkatan pendapatan atau penghasilan, mengurangi pengangguran serta akan mengurangi tingkat kemiskinan. (Mankiw, 2009). Pertumbuhan ekonomi yang rendah menurut Kuncoro (2014) akan membawa dampak pada rendahnya produktivitas, terbatasnya penciptaan lapangan kerja, pendapatan perkapita yang rendah, meningkatnya jumlah pengangguran dan meningkatnya jumlah penduduk miskin.

Upaya meningkatkan pertumbuhan ekonomi terus diupaya setiap daerah. Upaya meningkatkan pertumbuhan ekonomi dapat dilakukan, bila daerah mampu meningkatkan pengeluarannya yaitu dalam bentuk belanja daerah. Belanja daerah pada dasarnya adalah segala pengeluaran yang diperuntukkan untuk membiayai kegiatan atau program pembangunan yang telah ditetapkan oleh pemerintah dalam mendukung kelancaranaktivitas ekonomi masyarakat. Belanja daerah yang dilakukan digunakan untuk membiayai pembangunan sarana dan prasarana atau infrastruktur yang dibutuhkan dalampembangunan.

Belanja daerah dalam pelaksanaannya dapat berupa belanja langsung dan belanjatidak langsung. Belanja langsung adalah belanja yang dikeluarkan pemerintah dalam membiayai kegiatan atau program yang bersifat langsung menyentuh pada kepentingan masyarakat sementara belanja tidak langsung adalah belanja yang dikeluarkan pemerintah dalam membiayai kegiatan atau program yang bersifat tidak langsung menyentuh pada kepentingan masyarakat atau bersifat administratif. (Sumiyati, 2010).

Belanja daerah yang dilakukan Kabupaten Tebo selama tahun 2013-2018 rata-rata mengalami peningkatan setiap tahun sebesar 6,47 persen yaitu dari Rp. 748.554.305.711,14 pada tahun 2013 naik menjadi Rp. 878.860.323.749,78 pada tahun 2018. Belanja daerah yang mengalami peningkatan digunakan untuk membiayai kegiatan atau program dalam bentuk belanja langsung dan belanja tidak langsung yaitu belanja operasional, belanja tak terduga dan belanja modal.

Belanja daerah yang bersifat langsung menyentuh kepentingan masyarakat dapat dilakukan melalui belanja modal. Belanja modal sendiri dalam pelaksanaannya di daerah digunakan untuk membiayai pengeluaran dalam bentuk belanja tanah, belanja peralatan dan mesin, belanja gedung dan bangunan, belanja jalan, irigasi dan jaringan dan belanja aset lainnya. Belanja modal yang dilakukan daerah diharapkan mampu mendorong peningkatan perekonomian dan menciptakan lapangan kerja serta mengurangi tingkat kemiskinan atau jumlah penduduk miskin yang ada didaerah. (Peraturan Pemerintah Nomor 71 Tahun 2010 
dalam Winardi, 2010).

Peningkatan belanja daerah yang dilakukan melalui belanja modal terus mengalami peningkatan di Kabupaten Tebo. Selama enam tahun terakhir yaitu dari tahun 2013-2018, Belanja modal dibelanjakan adalah sebesar Rp. 271.774.153.279,00 pada tahun 2013 dan pada tahun 2018 sebesar Rp. 258.990.826.316,86 atau menurun, tetapi secara rata-rata meningkat sebesar 6,08 persen. Penurunan belanja modal terjadi pada tahun 2015-2017 yaitu masing-masing sebesar 31,29 persen, 4,79 persen dan 0,12 persen sedangkan pada tahun 2013, 2014 dan 2018 terjadi peningkatan masing-masing sebesar 30,25 persen, 31,60 persen dan 10,83 persen.

Peningkatan belanja modal selama tahun 2013-2018 pada Kabupaten Tebo sebagai belanja yang bertujuan untuk mendorong peningkatan aktivitas ekonomi daerah diharapkan mampu menciptakan lapangan kerja dan juga diharapkan mampu menampungtenaga kerja di setiap sektor yang pada akhirnya mampu mengurangi jumlah pengangguran yang ada. Selama enam tahun terakhir jumlah pengangguran di Kabupaten Tebo rata-rata meningkat setiap tahun sebesar 70,01 persen yaitu dari 1.024 jiwa pada tahun 2013 dan meningkat menjadi 3.691 jiwa pada tahun 2018. Peningkatan jumlah pengangguran yang terjadi sebgai akibat ada peningkatan yang sangat besar di tahun 2014 yaitu sebesar 528,81 persen dan penurunan jumlah pengangguran terjadi pada tahun 2013 dan 2015 yaitu masing-masing sebesar 66,85 persen dan 49,06 persen.

Pengurangan tingkat kemiskinan di Indonesia terus diupayakan setiap tahunnya oleh setiap daerah. Upaya ini juga dilakukan oleh pemerintah Kabupaten Tebo. Upaya pengurangan tingkat kemiskinan atau jumlah penduduk miskin terlihat walaupun hasil yang diperoleh tidak sesuai dengan tujuan yang diharapkan, tetapi upaya untuk merunkannya terus diupayakan oleh pemerintah Kabupaten Tebo selama enam tahun terakhir. Selama tahun 2013-2018, jumlah penduduk miskin di Kabupaten Tebo terjadi peningkatan yaitu rata-rata sebesar 2,43 persen. Jumlah penduduk miskin meningkat dari 21.967 jiwa pada tahun 2013 dan naik menjadi 22.858 jiwa pada tahun 2018. Jumlah penduduk miskin terjadi penurunan hanya di di tahun 2016 dan 2018 yaitu turun sebesar 2,26 persen dan 1,38 persen. Sementara tahun-tahun lainnya jumlah penduduk miskin terjadi peningkatan. Peningkatan jumlah penduduk miskin terbesar terjadi pada tahun 2013 yaitu sebesar 10,42 persen dengan jumlah penduduk miskin adalah 21.967 jiwa.

Berdasarkan uraian diatas, belanja modal, jumlah pengangguran dan jumlah kemiskinan di Kabupaten Tebo mengalami peningkatan. Kondisi ini bukanlah yang diharapkan, seharusnya peningkatan belanja modal yang dilakukan dapat mendorong terciptanya lapangan kerja yang besar dan mampu menyerap tenaga kerja dalam jumlah yang besar serta mampu mengurangi jumlah penduduk miskin di Kabupaten Tebo. Kondisi yang tidak sesuai dengan yang diharapkan dari variabel yang diukur diatas, mendorong penulistertarik untuk melakukan penelitian secara lebih mendalam tentang belanja modal, jumlah pengangguran dan jumlah kemiskinan di Kabupaten Tebo dalam bentuk tulisan skripsi dengan judul: "Analisis dampak belanja modal dan tingkat pengangguran terhadap tingkat kemiskinan di Kabupaten Tebo ".

Adapun tujuan dalam penelitian ini adalah, untuk mengukur dan menganalisis perkembangan dan pengaruh belanja modal dan tingkat pengangguran terhadap tingkat kemiskinan di Kabupaten Tebo selama tahun 2004-2018.

\section{METODE}

Data yang digunakan dalam penelitian ini adalah data sekunder. Arikunto (2010) menjelaskan, data sekunder adalah data yang diterbitkan dan dipublikasikan suatu kantor atau lembaga yang berbentuk data rentang waktu (time series). Data yang yang digunakan dalam penelitian ini adalah data tahunan selama tahun 2004-2018. 
Untuk menjawab tujuan pertama digunakan rumus sebagai berikut:

$$
P V_{i t}=\frac{V_{i t}-V_{i t-1}}{V_{i t-1}} \times 100 \%
$$

Dimana :

PVit = Persentase perkembangan variabel i tahun tertentu

Vit = Nilai variabel $\mathrm{i}$ tahun tertentu

Vit $-1=$ Nilai variabel i tahun sebelumnya

Untuk menjawab tujuan kedua digunakan rumus analisis regresi berganda.

$$
Y i=\beta 0+\beta_{1} \log X_{1 i}+\beta_{2} X_{2 i}+e i
$$

Dimana :

$$
\begin{array}{ll}
\text { Yi } & =\text { Variabel dependen } \\
\mathrm{X} 1 \mathrm{i}, \mathrm{X} 2 \mathrm{i} & =\text { Variabel independent } \\
\beta 0 & =\text { Konstanta/intersep } \\
\beta 1,2 & =\text { Koefisien regresi/slope } \\
\mathrm{ei} & =\text { Error term }
\end{array}
$$

\section{Uji F statistik}

Uji F statistik digunakan untuk menunjukkan pengaruh (signifikan) variabel independen yang dimasukkan dalam model secara bersama-sama terhadap variabel dependen atau untuk mengetahui proporsi variabel dependen yang dijelaskan oleh variabel independen secara bersama-sama. 1). Jika $\mathrm{H}_{0}: \mathrm{b}_{1}, \mathrm{~b}_{2}=0$, artinya secara serentak variabel bebas tidak mempunyai pengaruhyang signifikan terhadap variabel tidak bebas. 2).Jika Ha: $b_{1}, b_{2} \neq 0$, artinya secara serentak variabel bebas mempunyai pengaruh yang signifikan terhadap variabel tidak bebas.

\section{Kriteria pengambilan keputusan :}

$\mathrm{H}_{0}$ diterima, jika $\mathrm{F}$ statistik $<\mathrm{F}$ tabelHa diterima, jika $\mathrm{F}$ statistik $>\mathrm{F}$ table. Adapun nilai $\mathrm{F}$ hitung dapat di cari dengan cara :

$$
F_{\text {hitung }}=\frac{R_{2} / k-1}{1-R_{2} / n-k}
$$

Dimana :

$\mathrm{R}^{2}=$ Koefisien determinasi

$\mathrm{k}$ = Banyaknya variabel bebasn = banyaknya sampel/data

\section{Uji t statistik}

Uji t statistik merupakan suatu pengujian yang bertujuan untuk mengetahui masingmasing koefisien regresi signifikan atau tidak terhadap variabel dependen dengan mengenggap variabel independen lainnya konstan. Dalam uji $t$ ini digunakan perumusan bentuk hipotesis sebagai berikut: 1 ). Jika $\mathrm{H}_{0}: b_{i}=0$, artinya tidak ada pengaruh yang signifikan antara masing-masing variabel bebas dengan variabel tidak bebas. 2). Jika Ha : bi $\neq 0$, artinya ada pengaruh yang signifikan antara masing-masing variabel bebas dengan variabel tidak bebas.

Selanjutnya dilakukan pengujian dengan cara membandingkan nilai t statistik terhadap nilai t tabel. Kriteria pengambilan keputusan: 1). Ho diterima, jika $\mathrm{t}$ statistik $<\mathrm{t}$ tabel Ha diterima, jika $\mathrm{t}$ statistik $>\mathrm{t}$ table, 2).Adapun nilai $\mathrm{t}$ hitung dapat di cari dengan cara : 
Dimana :

$$
t_{\text {hitung }}=\frac{b_{i}}{S e\left(b_{i}\right)}
$$

$\overline{\mathrm{bi}}=$ Koefisien regresi parsial

$\mathrm{Se}(\mathrm{bi}) \quad=$ Standar deviasi koefisien

\section{Koefisien determinasi $\left(\mathbf{R}^{2}\right)$}

Koefisien determinasi $\left(\mathrm{R}^{2}\right)$ digunakan untuk mengetahui sampai sejauh mana ketepatan atau kecocokan garis regresi yang terbentuk dalam mewakili kelompok data hasil observasi. $\mathrm{R}^{2}$ menggambarkan bagian dari variasi total yang dapat diterangkan oleh model. Semakin besar nilai $\mathrm{R}^{2}$ (mendekati 1), maka ketepatannya dikatakan semakin baik. Adapun rumus untuk menentukan nilai koefisien determinasi dapat dilakukan dengan cara :

Dimana :

$$
R^{2}=\frac{E S S}{T S S}
$$

ESS $=$ Explaind sum of squares

$\mathrm{TSS}=$ Total sum of squares

\section{Uji aumsi klasik}

\section{Uji normalitas}

Wahyu (2009) menjelaskan bahwa uji distribusi normal adalah uji untukmengukur apakah data memiliki distribusi normal sehingga dapat dipakai dalam statistik parametrik (statistik inferensial). Pendugaan persamaan dengan menggunakan metode OLS yaitu data (residual) yang dibentuk model regresi linier terdistribusi normal, bukan variabel bebas ataupun variabel terikatnya. Metode yang digunakan untuk menguji normalitas adalah Jarque-Bera (JB) Test. Apabila probabilita JB hitung lebih besar dari 5\%, maka residual terdistribusi normal dan sebaliknya, apabila nilainya lebih kecil tidak cukup bukti untuk menyatakan bahwa residual terdistribusi normal.

\section{Uji multikolinearitas}

Uji multikolinearitas bertujuan untuk menguji apakah model regresi ditemukan adanya korelasi antar variabel independen. Jika ada multikolinearitas, maka akan kesulitan untuk dapat melihat pengaruh variabel penjelas terhadap variabel yang dijelaskan (Widarjono, 2013). Uji multikolinearitas dapat diketahui melalui nilai InflationVariance Factor (VIF). Jika nilai VIF melebihi angka 10 maka terdapat multikolinearitas atau melihat nilai koefisien determinasi (R2). Apabila hasil regresi nilai R2 lebih rendah dari R2 model utama, maka dapat disimpulkan tidak terjadi multikolinearitas antarvariabel independen atau sebaliknya. (Wahyu, 2009).

\section{Uji heteroskedastisitas}

Uji heterokedatisitas bertujuan untuk menguji apakah dalam model regresi terjadi ketidaksamaan variance dari residual satu pengamatan ke pengamatan yang lain atau untuk melihat penyebaran data. Jika variance dari residual satu pengamatan ke pengamatan yang lain tetap, maka disebut homokedastisitas dan jika berbeda disebut heteroskedastisitas. Uji heteroskedastisitas yang digunakan adalah metode Glejser Heterocedasricity Test. Untuk mendeteksi ada tidaknya heteroskedastisitas dengan membandingkan nilai obs*R-square pada alpa 0,05 dengan nilai tabel X2. Jika nilai obs*R-squared $>$ X2 tabel, maka lolos dari 
uji heteroskedastisitas, dan sebaliknya jika nilai obs*R-squared $<\mathrm{X} 2$ tabel, maka tidak lolos uji heteroskedastisitas. (Wahyu, 2009).

\section{Uji autokorelasi}

Autokorelasi digunakan untuk mengetahui apakah didalam model yang digunakan terdapat autokorelasi di antara variabel-variabel yang di amati. Ada tidaknya autokorelasi dalam penelitian ini menggunakan uji Breusch-Godfrey Serial Correlation LM Test. Kriteria untuk menentukan ada tidaknya masalah autokorelasi adalah dengan melihat nilai Prob. Obs*R-squared, jika nilai Prob. Obs*R-squared lebih besar dari tingkat alpha 0,05 (5\%) maka H0 diterima dan menolak Ha dan artinya tidak terjadi autokorelasi. Sebaliknya, apabila nilai Prob. Obs*R-squared lebih kecil dari 0,05 maka dapat disimpulkan terjadi autokorelasi. (Wahyu, 2009).

\section{HASIL DAN PEMBAHASAN}

\section{Perkembangan belanja modal}

Belanja modal di Kabupaten Tebo rata-rata mengalami peningkatan atau kenaikkan setiap tahun sebesar 20,99 persen. Peningkatan terlihat dari nilai riil belanja modalnya yaitu dari Rp. 43.913.576.437,15 pada tahun 2004 naik menjadi Rp. 258.990.826.316,86 di tahun 2018. Belanja modal Kabupaten Tebo mengalami peningkatan terbesar terjadi pada tahun 2006 yaittu naik sebesar 125,62 persen dan nilai belanja modalnya Rp. 139.705.641.990,50. Sementara belanja modal Kabupaten Tebo mengalami penurunan terbesar terjadi pada tahun 2009 yaittu turun sebesar 58,59 persendan nilai belanja modalnya Rp. 114.961.574.320,00.

\section{Perkembangan jumlah pengangguran}

Upaya mengurangi tingkat pengangguran juga dilakukan Kabupaten Tebo terus dilakukan setiap tahunya. Selama tahun 2004-2018, rata-rata jumlah pengangguran dilihat dari penduduk berusia 15 tahun keatas (pengangguran terbuka) mengalami peningkatan sebesar 28,58 persen dan setiap tahun mengalami naik turun. Jumlah pengangguran terbuka mengalami peningkatan terbesar terjadi di tahun 2014 yaitu 6.439 jiwa atau naik sebesar 528,81 persen. Sementara jumlah pengangguran terbuka mengalami penurunan terbesar jumlahnya terjadi pada tahun 2013 yaitu turun 66,85 persen dengan jumlah pengangguran adalah 1.024 jiwa.

\section{Perkembangan jumlah kemiskinan}

Upaya mengurangi jumlah penduduk miskin terus dilakukan Kabupaten Tebo setiap tahunya. Selama tahun 2004-2018, rata-rata jumlah penduduk miskin mengalami penurunan sebesar 0,42 persen. Dimana jumlah penduduk miskin di Kabupaten Tebo mengalami peningkatan terbesar terjadi pada tahun pada 2010 yaitu sebesar 20,88 persendengan jumlah penduduk miskin sebesar 19.170 jiwa. Jumlah penduduk miskin di Kabupaten Tebo mengalami penurunan terbesar terjadi pada tahun 2008 sebesar 24,20 persen dengan jumlah penduduk miskin sebesar 16.234 jiwa.

\section{Hasil analisis regresi berganda}

Analisis data dan pengujian hipotesis dalam penelitian ini dilakukan dengan menggunakan model regresi linear berganda semi logaritma. Analisis regresi linear berganda semi logaritma digunakan untuk menguji seberapa besar pengaruh belanja modal dan tingkat pengangguran terhadap tingkat kemiskinan di Kabupaten Tebo selama tahun 2004-2018. Untuk mengetahui bagaimana pengaruh antar variabel bebas terhadap variabel tidak bebas tersebut dilakukan dengan menggunakan persamaan regresi linear berganda semi logaritma sebagai berikut :

$\mathrm{TK}=\beta_{0}+\beta_{1} \log \mathrm{BM}_{1}+\beta_{2} \mathrm{TP}_{2}+\mathrm{e}$

Berdasarkan hasil perhitungan regresi linear berganda dengan menggunakan program 
Eviews 12.0 diperoleh perhitungan hasil sebagai berikut :

Tabel 1. Hasil regresi

\begin{tabular}{|c|c|c|c|c|}
\hline Variabel & Koefisien & Std. Error & t-statistic & Prob \\
\hline \multirow{2}{*}{$\begin{array}{l}\text { Konstanta Belanja Modal } \\
\text { Tingkat Pengangguran }\end{array}$} & 8.594958 & 21.67800 & 3.964830 & 0.0019 \\
\hline & -6.869632 & 1.864736 & -3.683971 & 0.0031 \\
\hline $\begin{array}{l}\mathrm{R}^{2}=0.862187 \\
\mathrm{t} \text { tabel }=1.771\end{array}$ & -2.344968 & 0.188437 & \multicolumn{2}{|c|}{$\begin{aligned} \text { Sig. F hitung } & =0.003963 \mathrm{~F} \text { tabel } \\
& =3.89\end{aligned}$} \\
\hline
\end{tabular}

Sumber: Data diolah, 2020

Hasil perhitungan regresi berganda diatas selanjutnya dapat ditulis dalam bentukpersamaan estimasi regresi berganda sebagai berikut:

TK $=8,594958-6,869632 B M 1-2,344968 T P 2$

Dimana:

TK = Tingkat kemiskinan

BM1 = Belanja modal

$\mathrm{TP} 2=$ Tingkat pengangguran

\section{Uji asumsi klasik}

\section{Uji multikolinearitas}

Hasil perhitungan, diperoleh nilai VIF untuk kedua variabel bebas (independen) yaitu belanja modal dan tingkat pengangguran adalah 2,109381 serta lebih kecil dari 10, maka antara variabel belanja modal dan tingkat pengangguran bebas dari multikolinearitas. Artinya di dalam model regresi tidak ditemukan korelasi antar variabelindependen, sehingga model ini telah memenuhi syarat asumsi klasik dalam analisis regresi berganda.

\section{Uji autokorelasi}

Hasil uji Breusch-Godfrey Serial Correlation LM Test yang telah dilakukan, didapatkan hasil nilai Prob Chi-Square (2) sebesar 0,2337. Pada saat nilai Prob Chi- Square (2) lebih besar dari tingkat alpha $0,05(5 \%)$ atau 0,2337 >0,05, maka model tidak terjadi autokorelasi, sehingga model ini telah memenuhi syarat asumsi klasik dalam analisis regresi berganda.

\section{Uji heteroskedastisitas}

Berdasarkan hasil Uji Glejser, diperoleh nilai Prob Chi-Square sebesar 0.7463. Pada saat nilai Prob Chi-Square lebih besar dari tingkat alpha 0,05 (5\%) atau 0,7463>0,05, maka model tidak terjadi heteroskedastisitas, sehingga model ini telah memenuhi syarat asumsi klasik dalam analisis regresi.

\section{Uji normalitas}

Berdasarkan hasil uji normalitas, diperoleh nilai Probabilitas Jarque-Bera sebesar 0,814922. Pada saat nilai Probabilitas Jarque-Bera lebih besar dari tingkat alpha 0,05 (5\%) atau $0,814922>0,05$, maka model memiliki residual yang terdistribusi normal dan asumsi klasik tentang kenormalan telah dipenuhi. 


\section{KESIMPULAN DAN SARAN}

\section{Kesimpulan}

Selama tahun 2004-2018 di Kabupaten Tebo, belanja modal rata-rata meningkat setiap tahun sebesar 20,99 persen, jumlah pengangguran rata-rata mengalami peningkatan sebesar 28,57 persen dan jumlah penduduk miskin rata-rata mengalami penurunan sebesar 0,42 persen. Belanja modal dan tingkat pengangguran miliki pengaruh dalam menurunkan tingkat kemiskinan di Kabupaten Tebo selama tahun 2004-2018. Hal ini dapat dilihat dari nilai koefisien regresi dari belanja modal dan tingkat pengangguran yang memiliki nilai koefisien regresi negative yaitu : $-6,869632$ dan $-2,344968$.

\section{Saran}

Belanja modal di Kabupaten Tebo dimasa datang perlu dipertahankan dan ditingkatkan. Belanja modal dapat ditingkatkan, jika pemerintah Kabupaten Tebo dapat menigkatkan penerimaan daerahnya melalui penerimaan PAD, dana perimbangan dan lainlain pendapatan daerah yang sah serta belanja daerah, terutama belanja modal dianggarkan lebih besar di banding belanja lainnya. Belanja modal yang dikeluarkan diarahkan pada kemampuan menyediakan infrastruktur yang dibutuhkan masyarakat dan mampu menciptakan lapangan kerja serta mengurangi jumlah penduduk miskin.

Kemampuan belanja modal dan tingkat pengangguran mengurangi tingkat kemiskinan, hendaknya dimasa datang pemerintah Kabupaten Tebo terus melakukan upaya mengurangi tingkat pengangguran melalui upaya penciptaan lapangan kerja, baik yang dilakukan oleh pemerintah sendiri maupun melibatkan pihak swasta atau pengusaha serta meningkatkan anggaran belanja modal, terutama menciptakan kesempatan kerja, melanjutkan program bantuan untuk masyarakat miskin dan menekan laju pertumbuhan penduduk.

\section{DAFTAR PUSTAKA}

Apri, Widyaningtyas, Nurhana. (2019). Analisis pengaruh PDRB, IPM dan pengangguran terhadap tingkat kemiskinan di Jawa Timur, Skripsi, Fakultas Ekonomi Dan Bisnis, Universitas Muhammadiyah: Surakarta.

Arsyad, Lincolin. (2015). Ekonomi pembangunan, UGM: Yogyakarta.

C Mustika, A Amril. (2015).Analisis Pengaruh Ekspor ke Jepang Terhadap Pertumbuhan Ekonomi dan Jumlah Pengangguran di Indonesia Periode 1993 sampai 2013, Jurnal Paradigma Ekonomika, 10 (1).

Haughton, Jonathan dan Shahidur R. Khandker. (2012), Pedoman tentang KemiskinanDan ketimpangan (handbook on poverty and inequality), Salemba Empat: Jakarta.

Kuncoro, Mudrajad. (2005), Otonomi dan pembangunan daerah: reformasi,perencanaan, strategi, dan peluang, Erlangga: Jakarta.

Kuncoro, Mudrajad. (2014). Dasar-dasar ekonomika pembangunan, edisi Kelima, UPP STIM YKPN: Yogyakarta.

Mankiw, Gregory N, (2009), Principles of economics (pengantar ekonomi mikro), Salemba Empat: Jakarta.

S Sunargo, D Hastuti. (2019).Mengatasi perilaku kerja kontraproduktif melalui peran integratif politik organisasional dan kecerdasan emosional pada era revolusi industri 4.0, Jurnal Paradigma Ekonomika 14 (2), 45-54

Wahyu, Wing, Winarno. (2009). Analisis ekonometrika dan statistika dengan eviews, edisi kedua, UPP STIM YKPN: Yogyakarta.

Widarjono, Agus. (2013). Ekonometrika pengantar dan aplikasinya, edisi keempat, upp stim ykpn: yogyakarta.

Widiastuti, Ari. (2010), Analisis faktor-faktor yang mempengaruhi kemiskinan di Jawa Tengah Tahun 2004-2008, Fakultas Ekonomi UNDIP: Semarang. 